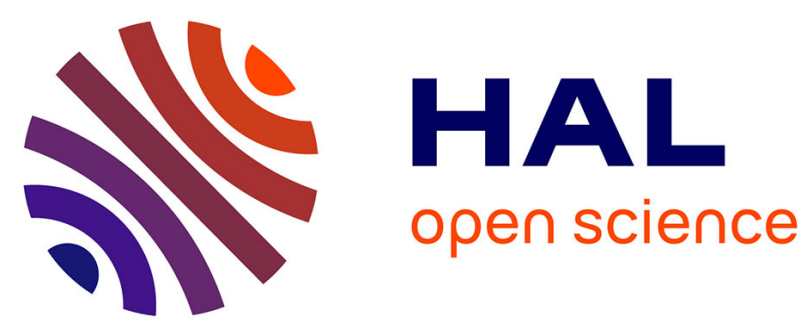

\title{
Intravenous immunoglobulin exerts reciprocal regulation of Th1/Th17 cells and regulatory $T$ cells in Guillain-Barré syndrome patients
}

Mohan S Maddur, Magalie Rabin, Pushpa Hegde, Francis Bolgert, Moneger Guy, Jean-Michel Vallat, Laurent Magy, Jagadeesh Bayry, Srini V Kaveri

\section{To cite this version:}

Mohan S Maddur, Magalie Rabin, Pushpa Hegde, Francis Bolgert, Moneger Guy, et al.. Intravenous immunoglobulin exerts reciprocal regulation of Th1/Th17 cells and regulatory T cells in Guillain-Barré syndrome patients. Immunologic Research, 2014, 60 (2-3), pp.320-329. 10.1007/s12026-014-8580-6 . hal-01102873

\section{HAL Id: hal-01102873 \\ https://hal.sorbonne-universite.fr/hal-01102873}

Submitted on 13 Jan 2015

HAL is a multi-disciplinary open access archive for the deposit and dissemination of scientific research documents, whether they are published or not. The documents may come from teaching and research institutions in France or abroad, or from public or private research centers.
L'archive ouverte pluridisciplinaire HAL, est destinée au dépôt et à la diffusion de documents scientifiques de niveau recherche, publiés ou non, émanant des établissements d'enseignement et de recherche français ou étrangers, des laboratoires publics ou privés. 


\title{
Intravenous immunoglobulin exerts reciprocal regulation of Th1/Th17 cells and regulatory $\mathbf{T}$ cells in Guillain-Barré syndrome patients
}

\author{
Mohan S Maddur", Magalie Rabin ${ }^{\#}$, Pushpa Hegde, \\ Francis Bolgert, Moneger Guy, Jean-Michel Vallat MD, Laurent Magy, Jagadeesh \\ Bayry and Srini V Kaveri
}

M.S. Maddur, M. Rabin, P. Hegde, J. Bayry, S.V. Kaveri : Institut National de la Santé et de la Recherche Médicale Unité 1138, Paris, F-75006, France

M.S. Maddur, M. Rabin, P. Hegde, J. Bayry, S.V. Kaveri : Centre de Recherche des Cordeliers, Equipe - Immunopathology and therapeutic immunointervention, Paris, F-75006, France

M.S. Maddur, J. Bayry, S.V. Kaveri : Sorbonne Universités, UMR S 1138, UPMC Univ Paris 06, Paris, F-75006, France

M.S. Maddur, J. Bayry, S.V. Kaveri : Université Paris Descartes, UMR S 1138, Paris, F75006, France

F. Bolgert, M. Guy: Réanimation Neurologique, Neurologie 1, Hôpital de la PitiéSalpêtrière, Paris, F-75651, France

J-M. Vallat, L. Magy: Centre de Référence ‘Neuropathies Périphériques Rares’ et Service de Neurologie, Hôpital Universitaire Limoges, F-87042 Limoges, France

J. Bayry, S.V. Kaveri : International Associated Laboratory IMPACT (Institut National de la Santé et de la Recherche Médicale, France - Indian Council of Medical Research, India), National Institute of Immunohaematology, Mumbai, 400012, India

${ }^{\#}$ M.S. Maddur, M. Rabin: These authors contributed equally 


\section{Corresponding authors:}

Jagadeesh Bayry : E-mail: jagadeesh.bayry@crc.jussieu.fr

Tel: 00331442782 03; Fax: 0033144278194

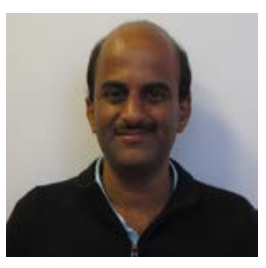

or Srini V Kaveri : E-mail: srini.kaveri@crc.jussieu.fr

Tel: 00331442782 01; Fax: 0033144278194

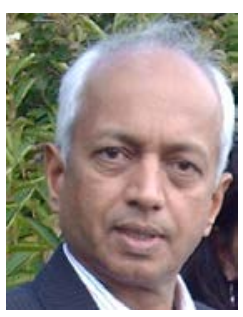




\begin{abstract}
Guillain-Barré syndrome (GBS) is an acute, autoimmune inflammatory disorder of peripheral nervous system characterized by a severe functional motor weakness. Treatment with intravenous immunoglobulin (IVIg) is one of the approved and preferred therapeutic strategies for GBS. However, the mechanisms underlying the therapeutic benefit with IVIg in GBS are not completely understood. In the present study, we observed that GBS patients have increased frequencies of Th1 and Th17 cells, but reduced number of Foxp $3^{+}$regulatory $\mathrm{T}$ cells ( $\mathrm{T}_{\text {reg }}$ cells) with defective functions. We show that IVIg treatment in GBS patients results in a marked reduction in the frequency of Th1 and Th17 cells with a concomitant expansion of $\mathrm{T}_{\text {reg }}$ cells. Importantly, IVIg-expanded $\mathrm{T}_{\text {reg }}$ cells exhibited an increased $\mathrm{T}$ cell suppressive function. Together our results demonstrate that therapeutic benefit of IVIg in GBS patients implicates the reciprocal regulation of Th1/Th17 and $\mathrm{T}_{\text {reg }}$ cells.
\end{abstract}

\title{
Key words
}

Intravenous immunoglobulin, IVIg, Guillain-barre syndrome, Th1 cells, Th17 cells, Regulatory T cells 


\section{Introduction}

Intravenous immunoglobulin (IVIg) is a therapeutic preparation, mainly of polyspecific IgG, obtained from the pooled plasma of several thousand healthy donors [1-3]. Although first used for immunoglobulin substitution in patients with immunodeficiencies, IVIg is now increasingly used in the treatment of several autoimmune and systemic inflammatory diseases [1, 4-7]. The therapeutic efficacy of IVIg in immunodeficiency as well as immune-mediated diseases is accomplished by bringing about homeostasis of dysregulated immune system, in addition to immunoglobulin replacement [8-14]. Although several mutually non-exclusive mechanisms are proposed [15-19], the cellular and molecular events underlying the therapeutic benefits of IVIg, particularly in autoimmune diseases, are still less understood.

Guillain-Barré syndrome (GBS) is an autoimmune, acute, inflammatory polyneuropathy of the peripheral nervous system. Despite an incidence rate of 0.6-4 per 100000 per year throughout the world, GBS is considered to be a frequent cause of neuromuscular paralysis at all ages [20-22]. There are several subtypes of GBS described. The axonal subtypes, such as acute motor axonal neuropathy (AMAN), and acute motor and sensory axonal neuropathy (AMSAN) are relatively rare and are predominantly caused by antibodies to gangliosides [20, 21]. Acute inflammatory demyelinating polyradiculoneuropathy (AIDP) with predominant motor deficit is the most common subtype of GBS and resembles experimental autoimmune neuritis (EAN), which is mainly caused by $\mathrm{T}$ cells reactive to myelin proteins $\mathrm{P} 0, \mathrm{P} 2$, and PMP22 [20]. The role of T-cell-mediated immunity in AIDP was unclear until recent studies revealed the increased frequency of Th1 as well as Th17 cells in the peripheral blood, and elevated levels of T-cell effector cytokines such as IFN- $\gamma$, IL-17 and IL-22 in the cerebrospinal fluid of GBS patients [23-26]. These findings are consistent with the observed pathogenic role of Th1 and Th17 cells in several autoimmune and inflammatory disease [2734] Furthermore, $\mathrm{CD} 4^{+} \mathrm{Foxp}^{+}$regulatory $\mathrm{T}\left(\mathrm{T}_{\text {reg }}\right)$ cells, which play critical role in the 
maintenance of immune tolerance and prevention of autoimmunity [35-44] are significantly reduced in GBS patients as well as EAN models [25, 45, 46]. Therefore, similar to other autoimmune inflammatory disease, therapeutic molecules that target both $\mathrm{T}_{\text {reg }}$ cells and effector $\mathrm{T}\left(\mathrm{T}_{\text {eff }}\right)$ cells (Th1 and Th17 cells) are being investigated for the treatment of GBS $[24,25]$.

In this context, IVIg is a proven effective treatment for GBS and is currently preferred over plasma exchange due to its similar efficacy, easier administration and more favourable sideeffect profile [21, 47-50]. Of particular interest, IVIg is found to induce expansion of Treg cells in vitro as well as in autoimmune patients and experimental animal models [51-62]. Furthermore, in addition to Th1 cells, recent evidences from experimental animal models as well as in vitro studies have shown that IVIg inhibits the development of Th17 cells and production of their effector molecules, including IL-17, IL-22 and GM-CSF [30, 63-67]. However, it is not clear whether the beneficial effects IVIg therapy in GBS and other autoimmune and inflammatory diseases is associated with the inhibition of Th1 and Th17 cells.

Since the up-regulation of $\mathrm{T}_{\text {reg }}$ cells and inhibition of $\mathrm{T}_{\text {eff }}$ cells is important for the alleviation of autoimmune inflammatory conditions [28, 68], and IVIg treatment of autoimmune patients is associated with restoration of immune homeostasis, we hypothesised that the beneficial effect of IVIg therapy in GBS patients is associated with reciprocal regulation of $\mathrm{T}_{\text {reg }}$ cells and effector Th1 and Th17 cell populations. 


\section{Materials and methods}

\section{Patients and healthy donors}

This is a multicentric study, consisting of 5 GBS patients and 4 healthy donors. Blood samples of control group were obtained from 4 healthy donors from Hôpital Hôtel Dieu, Etablissement Français du Sang, Paris, France with an appropriate ethical approval ( $\left.N^{\circ} 12 / E F S / 079\right)$. Patients with GBS were hospitalized between $15^{\text {th }}$ January 2011 and $31^{\text {st }}$ May 2011, in Neurological Department of Pitié-Salpétrière Hospital or Hôpital Universitaire of Limoges. Diagnosis of GBS was established according to criteria defined by Asbury et. al .[69]. Patients under the treatment of immunomodulatory or immunosuppressive drugs in 3 months prior to diagnosis of GBS, and those who were associated with other autoimmune disease and lymphoid disorders (lymphopenia $<1000 / \mathrm{mm}^{3}$, lymphoma, or infection with HIV) were excluded from the study. Five patients with the mean age of $67.6 \pm 4.2$ years were included in the study who fulfiled the diagnostic criteria. Relevant ethical committee approval (84-2012-08, CHU Limoges) and the consent from patients were obtained. The average onset of the neurological diseases was $11.6 \pm 2.8$ days at the time of patient inclusion in the study. All the patients included in the study showed AIDP, which is classical form of GBS.

\section{Clinical evaluation}

Patients with GBS were examined prior to the IVIg treatment and 1 week, 2 weeks and 4-5 weeks after the IVIg treatment, for their muscular weakness using Medical Research Council grading system (MRC), and for motor function disability based on modified Rankin scale (mRS). Briefly, the MRC sum score is a summation of the MRC grades (range, $0-5$ ) given in full numbers for the muscle pairs in hands and legs and that of mRS assigns grades ranging 
from 0 (no symptoms at all) to 5 (severe disability, bedridden, incontinent, and requiring constant nursing care and attention) [70, 71].

\section{Sample preparation and analyses of cellular populations by flow cytometry}

Blood samples (40-50 mL in lithium heparin) were obtained by peripheral venous blood at prior to the start of the treatment ( 0 week) and 1, 2 and 4-5 weeks after the treatment of IVIg. All the analyses were performed within $24 \mathrm{~h}$ following blood collection.

Peripheral blood mononuclear cells (PBMCs) were isolated by Ficoll-Paque $(1.077 \mathrm{~g} / \mathrm{ml})$ density centrifugation. PBMCs were then labelled with flurochrome conjugated antibodies to surface markers CD4 and then fixed and permeabilised using Foxp3 intracellular staining kit (eBioscience, France) according to the manufacturer's instructions to determine the $\mathrm{CD}^{+} \mathrm{Foxp}^{+} \mathrm{T}_{\text {reg }}$ cells.

For the intracellular detection of T cell cytokines (IFN- $\gamma$, TNF- $\alpha$, IL-4, IL-17 and IL-22), PBMCs were suspended in X-VIVO 15 culture medium (Lonza, France) and stimulated using phorbol 12-myristate 13-acetate (at $50 \mathrm{ng} / \mathrm{ml}$; PMA, Sigma, France) and ionomycin (at 500 $\mathrm{ng} / \mathrm{ml}$, Sigma, France) at $37^{\circ} \mathrm{C}$ for $4 \mathrm{~h}$, in the presence of GolgiStop (protein transport inhibitor; BD Biosciences, France). Different Th cell populations were identified by surface staining of CD4 and intracellular staining of $\mathrm{T}$ cell cytokines using Foxp3 staining kit (eBioscience). All flurochrome-conjugated antibodies were obtained from BD Biosciences, except for antibodies to IL-17A and Foxp3 (eBioscience). Around 50,000 cells/sample were acquired on flow cytometry (LSR II, BD Biosciences) using FACS DIVA ${ }^{\mathrm{TM}}$ and data were analysed using FlowJo software.

Functional analysis of $T_{\text {reg }}$ cells by $T$ cell suppression assay 
Using the PBMCs, untouched $\mathrm{CD}^{+} \mathrm{T}$ cells were isolated by negative selection using the $\mathrm{CD}^{+}$T-cell isolation kit II (Miltenyi Biotec, France). Further, naïve (CD45RA ${ }^{+}$) and memory (CD45RA $\left.{ }^{-}\right) \mathrm{CD}^{+} \mathrm{T}$ cells were separated using the CD45RA microbeads (Miltenyi Biotec) by positive selection. Finally, CD45RA ${ }^{-}$memory T cells were separated in to CD25 ${ }^{+}$ and CD25 cells using CD25 microbeads (Miltenyi Biotec). CD4 ${ }^{+}$CD45RA-CD25 ${ }^{+}$cells were used as $\mathrm{T}_{\text {reg }}$ cells and total $\mathrm{CD} 4^{+} \mathrm{CD} 25^{-}$cells were used as $\mathrm{T}_{\text {eff }}$ cells for the $\mathrm{T}$ cell suppression assay.

Ninety-six-well U-bottom plates were coated with $1.5 \mu \mathrm{g} / \mathrm{mL}$ anti-CD3 mAb (R\&D systems, France) for $2 \mathrm{~h}$ at $37^{\circ} \mathrm{C}$. Plates were then rinsed once with serum-free RPMI-1640 medium. $T_{\text {regs }}$ and $T_{\text {eff }}$ cells were co-cultured at different ratios ( $T_{\text {regs }}: T_{\text {eff }}$ at $\left.0: 1,1: 4,1: 2,1: 1\right)$ in serumfree $\mathrm{X}$-VIVO 15 medium in the presence of soluble anti-CD28 mAb $(1.0 \mu \mathrm{g} / \mathrm{mL}, \mathrm{R} \& \mathrm{D}$ systems) for 4 days at $37^{\circ} \mathrm{C}$. After 3 days, tritiated $\left[{ }^{3} \mathrm{H}\right]$ thymidine was added and $\mathrm{T}$ cell were cultured for another $18 \mathrm{~h}$. Subsequently, the cell culture plates were frozen at $-20^{\circ} \mathrm{C}$ for further analysis of $\left[{ }^{3} \mathrm{H}\right]$ thymidine incorporation by liquid scintillation to assess the degree of proliferation of $\mathrm{T}_{\text {eff }}$ cells and to determine the $\mathrm{T}$-cell suppressive function of $\mathrm{T}_{\text {reg }}$ cells. 


\section{Results}

\section{Treatment with IVIg ameliorates the functional motor deficit in GBS patients}

All GBS patients examined are elderly individuals, with a mean age of 67.6 years. The clinical examination scores for MRC and mRS of GBS patients before ( 0 week) and after (1, 2 and 4-5 weeks) IVIg treatment are depicted in the Fig 1. Notably, there was a wide variation in the degree of functional motor deficit prior to IVIg therapy among the GBS patients. Consistent with the previous studies [21, 47, 48], GBS patients treated with high dose IVIg (0.4 g/Kg body weight per day for 4 days) showed a clinical improvement as evidenced by the increase in MRC score and/or decrease in the modified Rankin scale. The clinical amelioration of GBS was observed as early as 1 week following initiation of IVIg therapy in the patients GBS-P1, -P2 and -P4, and from 2 weeks in GBS-P5 (Fig 1). However, no improvement was observed in GBS-P3 following IVIg treatment. Of note, GBS-P3 showed mild form of disease and failed to respond to IVIg therapy. The maximal improvement was seen in patient 1 , who had the most severe motor deficiency at the beginning. In summary, 4 out of 5 (80\%) patients responded to the IVIg therapy with a considerable improvement in their motor functions (Fig 1). In fact, the efficacy of IVIg in the treatment of severe form of GBS is well established, but not the mild form of disease [20, 21, 47]. This might explain the variations observed in the response to IVIg therapy within the cohort of GBS patients.

\section{IVIg decreases the circulating Th1 and Th17 cells in GBS patients}

After establishing the therapeutic efficacy of IVIg in GBS patients, we next investigated the cellular mechanisms mediating the clinical amelioration of disease. The present cohort of GBS patients showed the classical AIDP subtype of GBS, which is primarily caused by selfreactive $\mathrm{T}_{\text {eff }}$ cells. Since recent studies have indicated that Th1 and Th17 cells are associated 
with the severity of disease in GBS patients and EAN models [23-26], we evaluated the frequencies of different Th cell subsets in the blood of GBS patients.

Following the intracellular staining of PBMCs for T cell cytokines, such as IFN- $\gamma$, TNF- $\alpha$, IL-4, IL-17 and IL-22, different Th cell subsets were identified within the $\mathrm{CD}^{+} \mathrm{T}$ cells, including Th1 $\left(\mathrm{IFN}_{-} \gamma^{+}\right)$, Th17 $\left(\mathrm{IL}-17^{+}\right)$, Th22 (IL-22 $\left.{ }^{+}\right)$and Th2 (IL-4 $\left.{ }^{+}\right)$(Fig 2). Consistent with the previous reports [23-26], GBS patients showed increased frequencies of $T_{\text {eff }}$ cell subsets, such as Th1, Th17 and Th22, compared to the healthy donors (Fig 2a and b). TNF- $\alpha$ is a proinflammatory cytokine expressed mainly by inflammatory Th1 cells, but also Th17 and Th22 cells. Notably, the frequency of CD4 $4^{+}$Th cells expressing TNF- $\alpha$ is also elevated in the blood of GBS patients compared to healthy donors (Fig 2b). However, the frequency of Th2 cells, which are the primary $\mathrm{T}_{\text {eff }}$ cells implicated in allergic response, was similar to that of healthy donors (Fig 2c).

Interestingly, there was a marked decrease in the frequencies of IFN- $\gamma^{+}, \mathrm{TNF}-\alpha^{+}, \mathrm{IL}-17^{+}$and IL-22 ${ }^{+}$Th cells in the peripheral blood of GBS patients following IVIg therapy (Fig 2a and b). Despite the wide difference in the frequencies of Th cells before IVIg treatment among GBS patients, $T_{\text {eff }}$ cells were down-regulated to a similar levels following 4 weeks of IVIg therapy (except for IFN- $\gamma^{+}$Th cells). Further, the decline in the $\mathrm{T}_{\text {eff }}$ cells was drastic in GBSP1, -P2 and P4, who also had relatively severe form of disease (Fig 1 and 2). Notably, GBSP3 and -P5 showed a moderate change in Th cells, which is consistent with their response to IVIg therapy (Fig 1 and 2). Despite a moderate changes in the frequencies of IL- $4^{+}$Th cells, IVIg therapy does not appear to alter Th2 cells in GBS patients. Taken together, these results suggest that IVIg treatment selectively down-regulates the pathogenic $\mathrm{T}_{\text {eff }}$ cells involved in GBS. 


\section{IVIg therapy expands $\mathrm{CD}^{+}{ }^{+} \mathrm{Fxp}^{+}{ }^{+} \mathrm{T}_{\text {reg }}$ cells in GBS patients}

$\mathrm{CD}^{+}$Foxp3 $^{+} \mathrm{T}_{\text {reg }}$ cells play a critical role in sustaining immune homeostasis. While deficiency of $\mathrm{T}_{\text {reg }}$ cells is associated with autoimmune and inflammatory conditions, increased number of $\mathrm{T}_{\text {reg }}$ cells can lead to resolution of immune-mediated pathologies, which is associated with suppression of effector immune cells [35, 36, 38-40, 72, 73]. Therefore, we next explored whether the inhibition of $\mathrm{T}_{\text {eff }}$ cells by IVIg is associated with expansion of $\mathrm{T}_{\text {reg }}$ cells in GBS patients.

Compared to healthy donors, peripheral blood of GBS patients had lower frequency of $\mathrm{CD}^{+}{ }^{+}$oxp $^{+}{ }^{+} \mathrm{T}_{\text {reg }}$ cells prior to IVIg therapy, supporting the significance of $\mathrm{T}_{\text {reg }}$ cells in controlling autoimmune response (Fig 3a). Our recent report demonstrates that IVIg therapy leads to increase in the $\mathrm{T}_{\text {reg }}$ cell frequency one-week following IVIg treatment in GBS patients $\mathrm{P} 1, \mathrm{P} 2, \mathrm{P} 3$ and $\mathrm{P} 4$ and was asociated with an increased circulating prostagladin $\mathrm{E}_{2}$ [74]. In P4, the increase in $\mathrm{T}_{\text {reg }}$ cell was marginal. Here we followed the evolution of $\mathrm{T}_{\text {reg }}$ cells up to 4-5 weeks post-IVIg infusion. We observed that GBS-P4 showed a delayed increase (2-week) in $\mathrm{T}_{\text {reg }}$ cells and that of GBS-P5 failed to up-regulate $\mathrm{T}_{\text {reg }}$ cells. By $4^{\text {th }}$ week, $\mathrm{T}_{\text {reg }}$ frequency returned to day-0 level in three patients. However, two patients (P1 and P3) still showed high frequency of $\mathrm{T}_{\text {reg }}$ cells even after 4 weeks. Furthermore, $\mathrm{T}$ cells expressing Helios were also increased following IVIg therapy (Fig 3b). Notably, the ratio of $\mathrm{T}_{\text {eff }}$ to $\mathrm{T}_{\text {reg }}$ cell frequencies $\left(\mathrm{IFN}-\gamma^{+}\right.$:Foxp3+ and $\mathrm{IL}-17 \mathrm{~A}^{+}$:Foxp3+) showed a marked reduction in GBS patients (except P5) following IVIg treatment (Fig 3c). These findings indicate that IVIg induces expansion of Foxp3 ${ }^{+} \mathrm{T}_{\text {reg }}$ cells, which might be involved in suppression of $\mathrm{T}_{\text {eff }}$ cells to achieve amelioration of clinical disease. 


\section{$\mathbf{T}_{\text {reg }}$ cells expanded by IVIg are efficient in $\mathbf{T}$.cell suppression}

Finally, we examined the inhibition of $\mathrm{T}$ cell proliferation by enriched $\mathrm{T}_{\text {reg }}$ cells to assess the functional status. Consistent with other autoimmune studies, $\mathrm{T}_{\text {reg-enriched cells of } \mathrm{GBS}}$ patients prior to IVIg treatment were defective in suppression of $\mathrm{T}_{\text {eff }}$ cell proliferation, as compared to healthy donor (Fig 4). In contrast to $\mathrm{T}_{\text {reg }}$ cell number-dependent reduction in $\mathrm{T}_{\text {eff }}$ cell proliferation in healthy donor, $\mathrm{T}_{\text {reg-enriched cells from GBS patients (GBS-P1: pre-IVIg) }}$ promoted $\mathrm{T}_{\text {eff }}$ cell proliferation (Fig 4). Notably, following IVIg treatment, $\mathrm{T}_{\text {reg-enriched cells }}$ from GBS patients showed cell number-dependent reduction in $\mathrm{T}_{\text {eff }}$ cell proliferation (GBSP1: 1-week post-IVIg), similar to healthy donors (Fig 4). These results suggest that IVIg therapy induces expansion of $\mathrm{T}_{\text {reg }}$ cells with a restored $\mathrm{T}$-cell suppressive function in GBS patients. 


\section{Discussion}

In the present study, we showed that beneficial effect of IVIg therapy in GBS patients with AIPD is characterised by selective decrease in the frequencies of pathogenic Th1 and Th17 cells with a concomitant enrichment of $\mathrm{T}_{\text {reg }}$ cells showing restored $\mathrm{T}$-cell suppressive function. In contrast to the ability of B cells to promote Th2 polarization [75], treatment with natural antibodies (IVIg) did not alter the frequencies of Th2 cells in GBS patients. Our results thus indicate that the reciprocal regulation of $T_{\text {reg }}$ cells and $T_{\text {eff }}$ cell subsets is the cellular mechanism responsible for the therapeutic efficacy of IVIg in GBS and other autoimmune disease. Notably, similar to GBS, the restoration of imbalance between pathogenic $\mathrm{T}$ (Th1 and Th17) cells and $\mathrm{T}_{\text {reg }}$ cells by IVIg therapy is also observed in patients with Kawasaki disease, and also recurrent pregnancy loss [76, 77]. As size of GBS patient cohort was small, the present study results need to be validated with investigation of large cohort of patients.

Although the mechanistic events involved in the reciprocal regulation of $\mathrm{T}_{\text {reg }}$ cells and pathogenic Th1 and Th17 by IVIg in GBS patients are unclear, the findings of recent studies of in vitro cell culture as well as experimental mouse models have provided novel insights into mode of action of IVIg in autoimmune and inflammatory diseases. Interestingly, IVIg is found to inhibit the differentiation of naive CD4 T cells into pathogenic T (Th1 and Th17) cells and decreases the expression of effector molecules such as IFN- $\gamma$, IL-17 and IL-22 in human T cell culture [63-65], and in experimental autoimmune encephalomyelitis (EAE) mouse model [66, 67]. Mechanistically, IVIg directly interact with $\mathrm{T}$ cells to inhibit differentiation and function, mainly by interfering with the pathways involved in the induction of lineage-specific transcription factor, RORC [63]. Concomitantly, IVIg is shown to expand $\mathrm{T}_{\text {reg }}$ cells, mainly by inducing proliferation of pre-existing natural $\mathrm{T}_{\text {reg }}$ cells, rather 
than de novo generation from naive $T$ cells $[54,63]$. Notably, the reciprocal regulation of $\mathrm{T}_{\text {reg }}$ cells and Th17 in experimental autoimmune arthritis (EAA) mouse model by IVIg is found to be dependent on the up-regulation of IL-10 [78], which is an anti-inflammatory cytokine known to inhibit development and function of Th17 cells, but favour $\mathrm{T}_{\text {reg }}$ cells [29, 30]. It is possible that direct interaction of IVIg with Th cell susbets in GBS patients mediates the reciprocal regulation.

Of particular relevance, IVIg is also known to modulate the maturation, function and cytokine production of dendritic cells (DCs) [11, 79-84], which are the principal antigen presenting cells involved in development of $\mathrm{T}_{\text {reg }}$ cells and $\mathrm{T}_{\text {eff }}$ cell subsets during autoimmune response [85-87]. Consistent with this, interaction of IVIg with DCs is found to promote expansion of $\mathrm{T}_{\text {reg }}$ cells through different mechanisms, such as induction of cyclooxygenase-2dependent prostaglandin E2 $\left(\mathrm{PGE}_{2}\right)$ [88], Tregitopes[53, 89] and modulation of notch ligands[56, 88]. Interestingly, increased levels of $\mathrm{PGE}_{2}$ was observed in the peripheral blood of GBS patients following IVIg therapy [74]. Therefore, in addition to direct effect on T cells, IVIg-mediated modulation of DCs might be involved in regulation of Th cell subsets in IVIgtreated GBS patients.

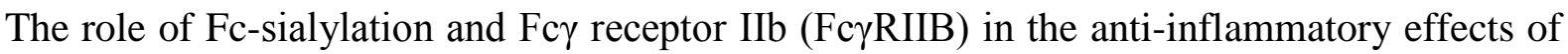
IVIg has been proposed [17]. It is hypothesised that $\alpha 2,6$-sialylated Fc fragments interact with dendritic cell-specific intercellular adhesion molecule-3-grabbing non-integrin-positive $\left(\mathrm{DC}-\mathrm{SIGN}^{+}\right.$) innate cells to release IL-33, which in turn expands the IL-4-producing basophils to mediate the anti-inflammatory effects [90]. Interestingly, studies performed with $\mathrm{F}(\mathrm{ab})_{2}$ and desialylated-IVIg have shown that both Fc fragment region of IVIg and Fc $\gamma \mathrm{RIIB}$ expression are dispensable for the expansion of Treg cells as well as suppression of pathogenic Th cells [63, 66, 67, 88], similar to IVIg-mediated modulation of human DCs [84, 
88, 91] and experimental autoimmune mouse models [66, 67, 92]. Of relevance, IVIg treatment induced a significant increase in the plasma levels of IL-33 to a similar extent in GBS patients, irrespective of Th cell modulation and therapeutic outcome (data not shown). These results support the recent findings of lack of correlation between the plasma IL-33 levels and the basophil number in autoimmune patients treated with IVIg [93]. Furthermore, basophils and sialylation of IVIg were not required for the therapeutic efficacy of IVIg in arthritis mouse models [94].

Since IVIg is known to contain cytokine-specific antibodies [1], it is possible that treatment of GBS patients with IVIg results in neutralization of inflammatory cytokines, which can in turn favour $\mathrm{T}_{\text {reg }}$ cell expansion, while inhibiting inflammatory Th1 and Th17 cell subsets [95]. In addition, IVIg can also directly interact with B cells to inhibit their activation proliferation and functions through induction of anergy and apoptosis [96-98]. These features of IVIg might be relevant in the axonal forms of GBS, which are mainly caused by antibodies to gangliosides [20, 21, 99]. Furthermore, IVIg is also found to target neutrophils to downregulate their activation and functions to exert anti-inflammatory mechanisms [100, 101], which may indirectly influence the development and function of Th cells. In summary, multitude of cellular and molecular mechanisms might be involved in the reciprocal regulation of effector $\mathrm{T}$ (Th1 and Th17) cells and $\mathrm{T}_{\text {reg }}$ cells by IVg therapy in GBS (Fig 5). Thus, IVIg exhibits the unique feature of pluripotency in order to achieve the therapeutic efficacy in diverse immune-mediated pathologies [102]. 


\section{Acknowledgments}

This study was supported by Institut National de la Santé et de la Recherche Médicale (INSERM), Centre National de la Recherche Scientifique (CNRS), Université Pierre et Marie Curie, Université Paris Descartes and Journées de Neurologie de Langue Française (M.R.) . This work is partially supported by financial support from CSL Behring France. 


\section{References}

1. Kazatchkine MD, Kaveri SV. Immunomodulation of autoimmune and inflammatory diseases with intravenous immune globulin. N Engl J Med. 2001;345(10):747-55.

2. Kaveri SV. Intravenous immunoglobulin: exploiting the potential of natural antibodies. Autoimmun Rev. 2012;11(11):792-4.

3. Seite JF, Shoenfeld Y, Youinou P, Hillion S. What is the contents of the magic draft IVIg? Autoimmun Rev. 2008;7(6):435-9.

4. Bayry J, Negi VS, Kaveri SV. Intravenous immunoglobulin therapy in rheumatic diseases. Nat Rev Rheumatol. 2011;7(6):349-59.

5. Dalakas MC. Intravenous immunoglobulin in autoimmune neuromuscular diseases. JAMA. 2004;291(19):2367-75.

6. Nussinovitch U, Shoenfeld Y. Intravenous immunoglobulin - indications and mechanisms in cardiovascular diseases. Autoimmun Rev. 2008;7(6):445-52.

7. Gelfand EW. Intravenous immune globulin in autoimmune and inflammatory diseases. N Engl J Med. 2012;367(21):2015-25.

8. Kaveri SV, Lacroix-Desmazes S, Bayry J. The antiinflammatory IgG. N Engl J Med. 2008;359(3):307-9.

9. Kaveri SV, Maddur MS, Hegde P, Lacroix-Desmazes S, Bayry J. Intravenous immunoglobulins in immunodeficiencies: more than mere replacement therapy. Clin Exp Immunol. 2011;164 Suppl 2:2-5.

10. Bayry J, Fournier EM, Maddur MS, Vani J, Wootla B, Siberil S et al. Intravenous immunoglobulin induces proliferation and immunoglobulin synthesis from B cells of patients with common variable immunodeficiency: a mechanism underlying the beneficial effect of IVIg in primary immunodeficiencies. J Autoimmun. 2011;36(1):915. 
11. Bayry J, Lacroix-Desmazes S, Donkova-Petrini V, Carbonneil C, Misra N, Lepelletier $\mathrm{Y}$ et al. Natural antibodies sustain differentiation and maturation of human dendritic cells. Proc Natl Acad Sci U S A. 2004;101(39):14210-5.

12. Bayry J, Lacroix-Desmazes S, Hermine O, Oksenhendler E, Kazatchkine MD, Kaveri SV. Amelioration of differentiation of dendritic cells from CVID patients by intravenous immunoglobulin. Am J Med. 2005;118(12):1439-40.

13. Bayry J, Lacroix-Desmazes S, Kazatchkine MD, Kaveri SV. Monoclonal antibody and intravenous immunoglobulin therapy for rheumatic diseases: rationale and mechanisms of action. Nat Clin Pract Rheumatol. 2007;3(5):262-72.

14. Vani J, Elluru S, Negi VS, Lacroix-Desmazes S, Kazatchkine MD, Bayry J et al. Role of natural antibodies in immune homeostasis: IVIg perspective. Autoimmun Rev. 2008;7(6):440-4.

15. Negi VS, Elluru S, Siberil S, Graff-Dubois S, Mouthon L, Kazatchkine MD et al. Intravenous immunoglobulin: an update on the clinical use and mechanisms of action. J Clin Immunol. 2007;27(3):233-45.

16. Tha-In T, Bayry J, Metselaar HJ, Kaveri SV, Kwekkeboom J. Modulation of the cellular immune system by intravenous immunoglobulin. Trends Immunol. 2008;29(12):608-15.

17. Schwab I, Nimmerjahn F. Intravenous immunoglobulin therapy: how does IgG modulate the immune system? Nat Rev Immunol. 2013;13(3):176-89.

18. Ballow M. The IgG molecule as a biological immune response modifier: mechanisms of action of intravenous immune serum globulin in autoimmune and inflammatory disorders. J Allergy Clin Immunol. 2011;127(2):315-23. 
19. Svetlicky N, Ortega-Hernandez OD, Mouthon L, Guillevin L, Thiesen HJ, Altman A et al. The advantage of specific intravenous immunoglobulin (sIVIG) on regular IVIG: experience of the last decade. J Clin Immunol. 2013;33 Suppl 1:S27-32.

20. Hughes RA, Cornblath DR. Guillain-Barre syndrome. Lancet. 2005;366(9497):165366.

21. van Doorn PA, Ruts L, Jacobs BC. Clinical features, pathogenesis, and treatment of Guillain-Barre syndrome. Lancet Neurol. 2008;7(10):939-50.

22. Eldar AH, Chapman J. Guillain Barre syndrome and other immune mediated neuropathies: diagnosis and classification. Autoimmun Rev. 2014;13(4-5):525-30.

23. Li S, Jin T, Zhang HL, Yu H, Meng F, Concha Quezada H et al. Circulating Th17, Th22, and Th1 Cells Are Elevated in the Guillain-Barre Syndrome and Downregulated by IVIg Treatments. Mediators Inflamm. 2014. doi:10.1155/2014/740947

24. Li XL, Dou YC, Liu Y, Shi CW, Cao LL, Zhang XQ et al. Atorvastatin ameliorates experimental autoimmune neuritis by decreased Th1/Th17 cytokines and up-regulated T regulatory cells. Cell Immunol. 2011;271(2):455-61.

25. Zhang HL, Zheng XY, Zhu J. Th1/Th2/Th17/Treg cytokines in Guillain-Barre syndrome and experimental autoimmune neuritis. Cytokine Growth Factor Rev. 2013;24(5):443-53.

26. Li S, Yu M, Li H, Zhang H, Jiang Y. IL-17 and IL-22 in cerebrospinal fluid and plasma are elevated in Guillain-Barre syndrome. Mediators Inflamm. 2012;2012:260473.

27. Goverman J. Autoimmune T cell responses in the central nervous system. Nat Rev Immunol. 2009;9(6):393-407. 
28. Korn T, Bettelli E, Oukka M, Kuchroo VK. IL-17 and Th17 Cells. Annu Rev Immunol. 2009;27:485-517.

29. Miossec P, Korn T, Kuchroo VK. Interleukin-17 and Type 17 Helper T Cells. New England Journal of Medicine. 2009;361(9):888-98.

30. Maddur MS, Miossec P, Kaveri SV, Bayry J. Th17 cells: biology, pathogenesis of autoimmune and inflammatory diseases, and therapeutic strategies. Am J Pathol. 2012;181(1):8-18.

31. Roark CL, Huang Y, Jin N, Aydintug MK, Casper T, Sun D et al. A canonical $\mathrm{V} \gamma 4 \mathrm{~V} \delta 4+\gamma \delta \mathrm{T}$ cell population with distinct stimulation requirements which promotes the Th17 response. Immunol Res. 2013; 55(1-3):217-230.

32. Sharma M, Kaveri SV, Bayry J. Th17 cells, pathogenic or not? TGF- $\beta 3$ imposes the embargo. Cell Mol Immunol. 2013; 10 (2):101-102.

33. Fiocco U, Accordi B, Martini V, Oliviero F, Facco M, Cabrelle A et al. JAK/STAT/PKC $\delta$ molecular pathways in synovial fluid T lymphocytes reflect the in vivo T helper-17 expansion in psoriatic arthritis. Immunol Res. 2014; 58 (1):61-69.

34. Su Z, Sun Y, Zhu H, Liu Y, Lin X, Shen H, et al. Th17 cell expansion in gastric cancer may contribute to cancer development and metastasis. Immunol Res. 2014; 58 (1):118-124.

35. Rudensky AY. Regulatory T cells and Foxp3. Immunol Rev. 2011;241(1):260-8.

36. Sakaguchi S, Vignali DA, Rudensky AY, Niec RE, Waldmann H. The plasticity and stability of regulatory T cells. Nat Rev Immunol. 2013;13(6):461-7.

37. Wehrens EJ, Prakken BJ, van Wijk F. T cells out of control--impaired immune regulation in the inflamed joint. Nat Rev Rheumatol. 2013; 9 (1):34-42.

38. Sakaguchi S, Yamaguchi T, Nomura T, Ono M. Regulatory T cells and immune tolerance. Cell. 2008;133(5):775-87. 
39. Wing K, Sakaguchi S. Regulatory T cells exert checks and balances on self tolerance and autoimmunity. Nat Immunol. 2010;11(1):7-13.

40. Andre S, Tough DF, Lacroix-Desmazes S, Kaveri SV, Bayry J. Surveillance of antigen-presenting cells by CD4+ CD25+ regulatory $\mathrm{T}$ cells in autoimmunity: immunopathogenesis and therapeutic implications. Am J Pathol. 2009;174(5):157587.

41. Kobezda T, Ghassemi-Nejad S, Mikecz K, Glant TT, Szekanecz Z. Of mice and men: how animal models advance our understanding of T-cell function in RA. Nat Rev Rheumatol. 2014; 10 (3):160-170.

42. Pellerin L, Jenks JA, Begin P, Bacchetta R, Nadeau KC. Regulatory T cells and their roles in immune dysregulation and allergy. Immunol Res. 2014; 58 (2-3):358-368.

43. Pedroza-Pacheco I, Madrigal A, Saudemont A. Interaction between natural killer cells and regulatory T cells: perspectives for immunotherapy. Cell Mol Immunol. 2013; 10 (3) :222-229.

44. Lin SJ, Lu CH, Yan DC, Lee PT, Hsiao HS, Kuo ML. Expansion of regulatory T cells from umbilical cord blood and adult peripheral blood CD4(+)CD25(+) T cells. Immunol Res. 2014; 60 (1):105-111.

45. Harness J, McCombe PA. Increased levels of activated T-cells and reduced levels of CD4/CD25+ cells in peripheral blood of Guillain-Barre syndrome patients compared to controls. J Clin Neurosci. 2008;15(9):1031-5.

46. Chi LJ, Wang HB, Zhang Y, Wang WZ. Abnormality of circulating CD4(+)CD25(+) regulatory $\mathrm{T}$ cell in patients with Guillain-Barre syndrome. J Neuroimmunol. 2007;192(1-2):206-14.

47. Hughes RA, Swan AV, van Doorn PA. Intravenous immunoglobulin for GuillainBarre syndrome. Cochrane Database Syst Rev. 2012;7:CD002063. 
48. van Doorn PA, Kuitwaard K, Walgaard C, van Koningsveld R, Ruts L, Jacobs BC: IVIG treatment and prognosis in Guillain-Barre syndrome, J Clin Immunol 2010, 30 Suppl 1:S74-78.

49. El-Bayoumi MA, El-Refaey AM, Abdelkader AM, El-Assmy MM, Alwakeel AA, ElTahan HM. Comparison of intravenous immunoglobulin and plasma exchange in treatment of mechanically ventilated children with Guillain Barre syndrome: a randomized study. Crit Care. 2011;15(4):R164.

50. Harel M, Shoenfeld Y. Intravenous immunoglobulin and Guillain-Barre syndrome. Clin Rev Allergy Immunol. 2005;29(3):281-7.

51. Maddur MS, Othy S, Hegde P, Vani J, Lacroix-Desmazes S, Bayry J et al. Immunomodulation by intravenous immunoglobulin: role of regulatory T cells. J Clin Immunol. 2010;30 Suppl 1:S4-8.

52. Bayry J, Mouthon L, Kaveri SV. Intravenous immunoglobulin expands regulatory T cells in autoimmune rheumatic disease. J Rheumatol. 2012;39(2):450-1.

53. De Groot AS, Moise L, McMurry JA, Wambre E, Van Overtvelt L, Moingeon P et al. Activation of natural regulatory T cells by IgG Fc-derived peptide "Tregitopes". Blood. 2008;112(8):3303-11.

54. Ephrem A, Chamat S, Miquel C, Fisson S, Mouthon L, Caligiuri G et al. Expansion of CD4+CD25+ regulatory $\mathrm{T}$ cells by intravenous immunoglobulin: a critical factor in controlling experimental autoimmune encephalomyelitis. Blood. 2008;111(2):715-22.

55. Kessel A, Ammuri H, Peri R, Pavlotzky ER, Blank M, Shoenfeld Y et al. Intravenous immunoglobulin therapy affects $\mathrm{T}$ regulatory cells by increasing their suppressive function. J Immunol. 2007;179(8):5571-5.

56. Massoud AH, Guay J, Shalaby KH, Bjur E, Ablona A, Chan D et al. Intravenous immunoglobulin attenuates airway inflammation through induction of forkhead box 
protein 3-positive regulatory T cells. J Allergy Clin Immunol. 2012;129(6):1656-65 e3.

57. Massoud AH, Yona M, Xue D, Chouiali F, Alturaihi H, Ablona A et al. Dendritic cell immunoreceptor: a novel receptor for intravenous immunoglobulin mediates induction of regulatory T cells. J Allergy Clin Immunol. 2014;133(3):853-63 e5.

58. Olivito B, Taddio A, Simonini G, Massai C, Ciullini S, Gambineri E et al. Defective FOXP3 expression in patients with acute Kawasaki disease and restoration by intravenous immunoglobulin therapy. Clin Exp Rheumatol. 2010;28(1 Suppl 57):937.

59. Tha-In T, Metselaar HJ, Bushell AR, Kwekkeboom J, Wood KJ. Intravenous immunoglobulins promote skin allograft acceptance by triggering functional activation of CD4+Foxp3+ T cells. Transplantation. 2010;89(12):1446-55.

60. Tsurikisawa N, Saito H, Oshikata C, Tsuburai T, Akiyama K. High-dose intravenous immunoglobulin treatment increases regulatory $\mathrm{T}$ cells in patients with eosinophilic granulomatosis with polyangiitis. J Rheumatol. 2012;39(5):1019-25.

61. Trinath J, Hegde P, Sharma M, Maddur MS, Rabin M, Vallat JM et al. Intravenous immunoglobulin expands regulatory $\mathrm{T}$ cells via induction of cyclooxygenase-2dependent prostaglandin E2 in human dendritic cells. Blood. 2013;122(8):1419-27.

62. Tjon AS, Tha-In T, Metselaar HJ, van Gent R, van der Laan LJ, Groothuismink ZM et al. Patients treated with high-dose intravenous immunoglobulin show selective activation of regulatory T cells. Clin Exp Immunol. 2013;173(2):259-67.

63. Maddur MS, Vani J, Hegde P, Lacroix-Desmazes S, Kaveri SV, Bayry J. Inhibition of differentiation, amplification, and function of human TH17 cells by intravenous immunoglobulin. J Allergy Clin Immunol. 2011;127(3):823-30 e1-7. 
64. Maddur MS, Kaveri SV, Bayry J. Comparison of different IVIg preparations on IL-17 production by human Th17 cells. Autoimmun Rev. 2011;10(12):809-10.

65. Maddur MS, Sharma M, Hegde P, Lacroix-Desmazes S, Kaveri SV, Bayry J. Inhibitory effect of IVIG on IL-17 production by Th17 cells is independent of anti-IL17 antibodies in the immunoglobulin preparations. J Clin Immunol. 2013;33 Suppl 1:S62-6.

66. Othy S, Hegde P, Topcu S, Sharma M, Maddur MS, Lacroix-Desmazes S et al. Intravenous gammaglobulin inhibits encephalitogenic potential of pathogenic $\mathrm{T}$ cells and interferes with their trafficking to the central nervous system, implicating sphingosine-1 phosphate receptor 1-mammalian target of rapamycin axis. J Immunol. 2013;190(9):4535-41.

67. Othy S, Topcu S, Saha C, Kothapalli P, Lacroix-Desmazes S, Kasermann F et al. Sialylation may be dispensable for reciprocal modulation of helper $\mathrm{T}$ cells by intravenous immunoglobulin. Eur J Immunol. 2014; 44(7):2059-63.

68. Liu G, Yang K, Burns S, Shrestha S, Chi H. The S1P(1)-mTOR axis directs the reciprocal differentiation of T(H)1 and T(reg) cells. Nat Immunol. 2010;11(11):104756.

69. Asbury AK, Cornblath DR. Assessment of current diagnostic criteria for GuillainBarre syndrome. Ann Neurol. 1990;27 Suppl:S21-4.

70. Merkies IS, Schmitz PI, van der Meche FG, Samijn JP, van Doorn PA. Clinimetric evaluation of a new overall disability scale in immune mediated polyneuropathies. J Neurol Neurosurg Psychiatry. 2002;72(5):596-601.

71. Graham RC, Hughes RA. A modified peripheral neuropathy scale: the Overall Neuropathy Limitations Scale. J Neurol Neurosurg Psychiatry. 2006;77(8):973-6. 
72. Ohkura N, Kitagawa Y, Sakaguchi S. Development and maintenance of regulatory T cells. Immunity. 2013;38(3):414-23.

73. Bayry J, Siberil S, Triebel F, Tough DF, Kaveri SV. Rescuing CD4+CD25+ regulatory T-cell functions in rheumatoid arthritis by cytokine-targeted monoclonal antibody therapy. Drug Discov Today. 2007;12(13-14):548-552.

74. Maddur MS, Trinath J, Rabin M, Vallat JM, Magy L, Balaji KN et al. Intravenous immunoglobulin-mediated expansion of regulatory $\mathrm{T}$ cells in autoimmune patients is associated with an increased prostaglandin E2 in the circulation. Cell Mol Immunol. 2015 (in press).

75. Maddur MS, Sharma M, Hegde P, Stephen-Victor E, Pulendran B, Kaveri SV et al. Human B cells induce dendritic cell maturation and favour Th2 polarization by inducing OX-40 ligand. Nat Commun. 2014;5:4092. doi: 10.1038/ncomms5092.

76. Jia S, Li C, Wang G, Yang J, Zu Y. The T helper type 17/regulatory T cell imbalance in patients with acute Kawasaki disease. Clin Exp Immunol. 2010;162(1):131-7.

77. Kim DJ, Lee SK, Kim JY, Na BJ, Hur SE, Lee M et al. Intravenous immunoglobulin g modulates peripheral blood Th17 and Foxp3(+) regulatory T cells in pregnant women with recurrent pregnancy loss. Am J Reprod Immunol. 2014;71(5):441-50.

78. Lee SY, Jung YO, Ryu JG, Kang CM, Kim EK, Son HJ et al. Intravenous immunoglobulin attenuates experimental autoimmune arthritis by inducing reciprocal regulation of th17 and treg cells in an interleukin-10-dependent manner. Arthritis Rheumatol. 2014;66(7):1768-78.

79. Bayry J, Lacroix-Desmazes S, Carbonneil C, Misra N, Donkova V, Pashov A et al. Inhibition of maturation and function of dendritic cells by intravenous immunoglobulin. Blood. 2003;101(2):758-65. 
80. Bayry J, Lacroix-Desmazes S, Delignat S, Mouthon L, Weill B, Kazatchkine MD et al. Intravenous immunoglobulin abrogates dendritic cell differentiation induced by interferon-alpha present in serum from patients with systemic lupus erythematosus. Arthritis Rheum. 2003;48(12):3497-502.

81. Bayry J, Lacroix-Desmazes S, Kazatchkine MD, Hermine O, Tough DF, Kaveri SV. Modulation of dendritic cell maturation and function by B lymphocytes. J Immunol. 2005;175(1):15-20.

82. Aubin E, Lemieux R, Bazin R. Indirect inhibition of in vivo and in vitro T-cell responses by intravenous immunoglobulins due to impaired antigen presentation. Blood. 2010;115(9):1727-34.

83. Othy S, Bruneval P, Topcu S, Dugail I, Delers F, Lacroix-Desmazes S et al. Effect of IVIg on human dendritic cell-mediated antigen uptake and presentation: role of lipid accumulation. J Autoimmun. 2012;39(3):168-72.

84. Wiedeman AE, Santer DM, Yan W, Miescher S, Kasermann F, Elkon KB. Contrasting mechanisms of interferon-alpha inhibition by intravenous immunoglobulin after induction by immune complexes versus Toll-like receptor agonists. Arthritis Rheum. 2013;65(10):2713-23.

85. Steinman RM, Banchereau J. Taking dendritic cells into medicine. Nature. 2007;449(7161):419-26.

86. Ganguly D, Haak S, Sisirak V, Reizis B. The role of dendritic cells in autoimmunity. Nat Rev Immunol. 2013;13(8):566-77.

87. Vitali C, Mingozzi F, Broggi A, Barresi S, Zolezzi F, Bayry J et al. Migratory, and not lymphoid-resident, dendritic cells maintain peripheral self-tolerance and prevent autoimmunity via induction of iTreg cells. Blood. 2012;120(6):1237-45. 
88. Trinath J, Hegde P, Balaji KN, Kaveri SV, Bayry J. Intravenous immunoglobulinmediated regulation of Notch ligands on human dendritic cells. J Allergy Clin Immunol. 2013;131(4):1255-7, 7 e1.

89. Cousens LP, Tassone R, Mazer BD, Ramachandiran V, Scott DW, De Groot AS. Tregitope update: mechanism of action parallels IVIg. Autoimmun Rev. 2013;12(3):436-43.

90. Anthony RM, Kobayashi T, Wermeling F, Ravetch JV. Intravenous gammaglobulin suppresses inflammation through a novel $\mathrm{T}(\mathrm{H}) 2$ pathway. Nature. 2011;475(7354):110-3.

91. Bayry J, Bansal K, Kazatchkine MD, Kaveri SV. DC-SIGN and alpha2,6-sialylated IgG Fc interaction is dispensable for the anti-inflammatory activity of IVIg on human dendritic cells. Proc Natl Acad Sci U S A. 2009;106(9):E24.

92. Leontyev D, Katsman Y, Branch DR. Mouse background and IVIG dosage are critical in establishing the role of inhibitory Fcgamma receptor for the amelioration of experimental ITP. Blood. 2012;119(22):5261-4.

93. Sharma M, Schoindre Y, Hegde P, Saha C, Maddur MS, Stephen-Victor E et al. Intravenous immunoglobulin-induced IL-33 is insufficient to mediate basophil expansion in autoimmune patients. Sci Rep. 2014;4:5672. doi:doi:10.1038/srep05672.

94. Campbell IK, Miescher S, Branch DR, Mott PJ, Lazarus AH, Han D et al. Therapeutic effect of IVIG on inflammatory arthritis in mice is dependent on the Fc portion and independent of sialylation or basophils. J Immunol. 2014;192(11):5031-8.

95. Bayry J, Lacroix-Desmazes S, Dasgupta S, Kazatchkine MD, Kaveri SV. Efficacy of regulatory T-cell immunotherapy: are inflammatory cytokines key determinants? Nat Rev Immunol. 2008;8(1):1p following 86. 
96. Maddur MS, Hegde P, Sharma M, Kaveri SV, Bayry J. B cells are resistant to immunomodulation by 'IVIg-educated' dendritic cells. Autoimmun Rev. 2011;11(2):154-6.

97. Seite JF, Cornec D, Renaudineau Y, Youinou P, Mageed RA, Hillion S. IVIg modulates BCR signaling through CD22 and promotes apoptosis in mature human B lymphocytes. Blood. 2010;116(10):1698-704.

98. Seite JF, Goutsmedt C, Youinou P, Pers JO, Hillion S. Intravenous immunoglobulin induces a functional silencing program similar to anergy in human B cells. J Allergy Clin Immunol. 2014;133(1):181-8 e1-9.

99. Moriguchi K, Miyamoto K, Takada K, Kusunoki S. Four cases of anti-ganglioside antibody-positive neuralgic amyotrophy with good response to intravenous immunoglobulin infusion therapy. J Neuroimmunol. 2011;238(1-2):107-9.

100. Casulli S, Topcu S, Fattoum L, von Gunten S, Simon HU, Teillaud JL et al. A differential concentration-dependent effect of IVIg on neutrophil functions: relevance for anti-microbial and anti-inflammatory mechanisms. PLoS One. 2011;6(10):e26469.

101. Semple JW, Kim M, Hou J, McVey M, Lee YJ, Tabuchi A et al. Intravenous immunoglobulin prevents murine antibody-mediated acute lung injury at the level of neutrophil reactive oxygen species (ROS) production. PLoS One. 2012;7(2):e31357.

102. von Gunten S, Shoenfeld Y, Blank M, Branch DR, Vassilev T, Kasermann F et al. IVIG pluripotency and the concept of Fc-sialylation: challenges to the scientist. Nat Rev Immunol. 2014;14(5):349. 


\section{Figure Legend}

Fig. 1 Changes in the clinical evaluation score of GBS patients over time following IVIg therapy Clinical examination of GBS patients was done before and after 1, 2 and 4-5 weeks of IVIg administration for assessing the muscular weakness by Medical Research council (MRC) sum score and the motor function disability by modified Rankin scale (mRS).
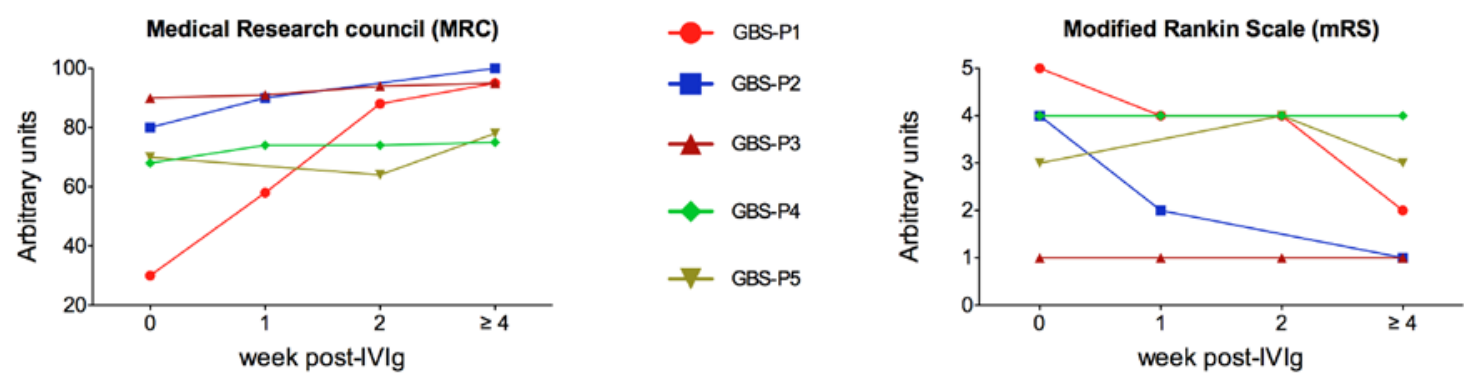
Fig. 2 Temporal changes in the frequency of circulating effector CD4+ Th cell subsets in GBS patients following IVIg therapy PBMCs from GBS patients were analysed by staining of surface CD4 and intracellular T cell cytokines. a-c The percentage of $\mathrm{CD}^{+}{ }^{+} \mathrm{Th}$ cells expressing IFN- $\gamma$, IL-17A, TNF- $\alpha$, IL-22 and IL-4 was determined by flow cytometry at different time-interval before and after IVIg treatment.
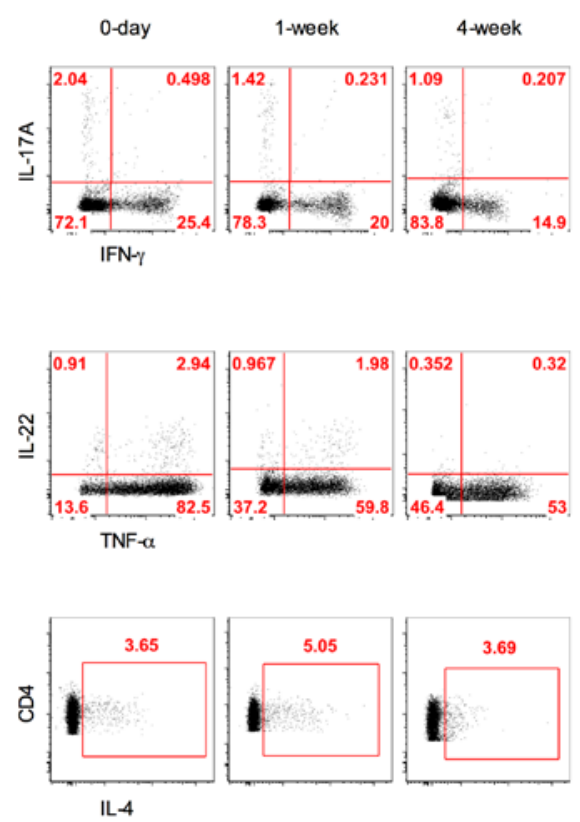

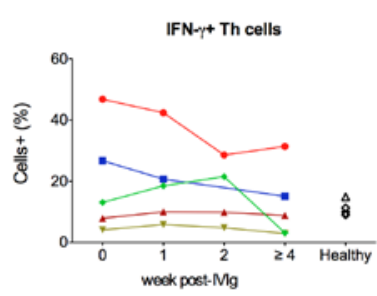

TNF- $\alpha+$ Th cells

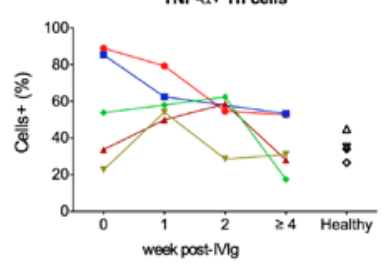

IL-4+ Th cells

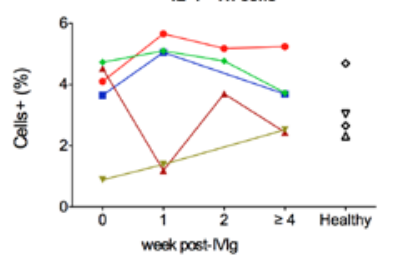

IL-17A+ Th cells

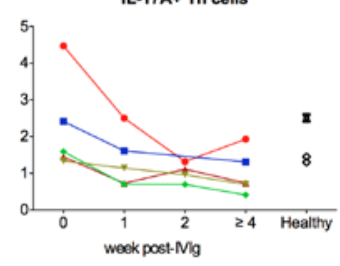

IL-22+ Th cells

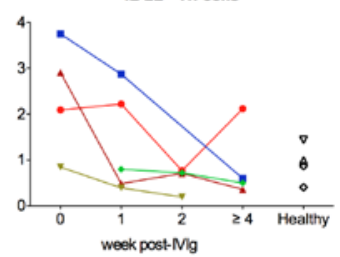

- GBSP1 $\quad$ GBS-P3

$\rightarrow$ GBS-P2 $\rightarrow$ GBS-P4

$\mp$ GBS.P5 
Fig. 3 Temporal changes in the frequency of circulating Foxp3+CD4+ regulatory $T$ ( $T_{\text {reg}}$ ) cell population in GBS patients following IVIg therapy PBMCs from GBS patients were analysed by staining of surface CD4 and intracellular Foxp3. a, b The percentage of CD4 ${ }^{+}$Th cells expressing Foxp3 and Helios was determined by flow cytometry at different time-interval before and after IVIg treatment. The $\mathrm{T}_{\text {reg }}$ frequency of day zero and 1 week is from the previous report ${ }^{74}$. $\mathbf{c}$ The ratio of $\mathrm{CD}^{+}$Th cells expressing IFN- $\gamma$ to that of Foxp3 and IL-17A to that of Foxp3.

a

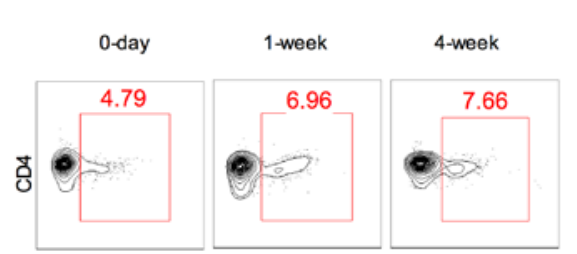

Foxp3+

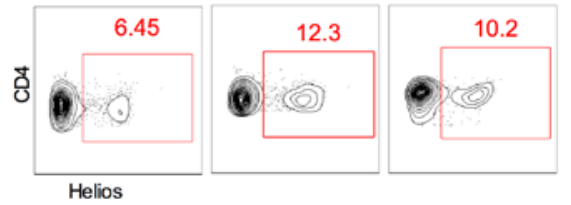

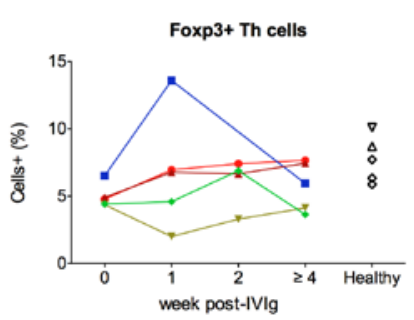

- GBSP1 $\leadsto$ GBSP4

- GBSP2 7 GBS.P5

¿ GBS.P3

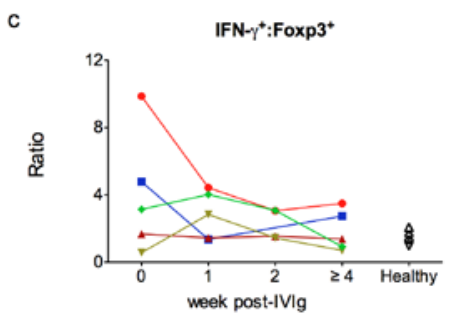

IL-17A ${ }^{+}:$Foxp3 $3^{+}$

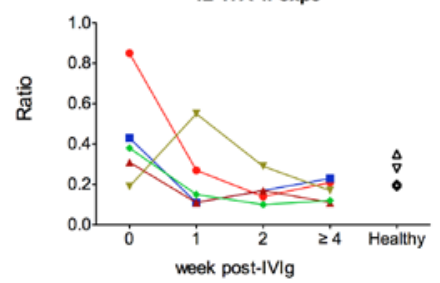


Fig. $4 \mathrm{~T}$ cell suppressive function of regulatory $T\left(T_{\text {reg }}\right)$ cell population is restored in GBS patients following IVIg therapy $\mathrm{T}_{\text {reg }}$-enriched cells and effector $\mathrm{T}\left(\mathrm{T}_{\text {eff }}\right)$ cells isolated from PBMCs of GBS patients were co-cultured in quadruplicates at different ratios $\left(\mathrm{T}_{\text {regs }}: \mathrm{T}_{\text {eff }}\right.$ at 1:4, 1:2, 1:1) in serum-free X-VIVO 15 medium in the presence of plate-bound anti-CD3 and soluble anti-CD28 mAb for 4 days at $37^{\circ} \mathrm{C}$. $\mathrm{T}$ cell proliferation (upper panels) was determined by $\left[{ }^{3} \mathrm{H}\right]$ thymidine incorporation assay. Percentage change in proliferation of $\mathrm{T}_{\text {eff }}$ cells in the presence of increasing number of $\mathrm{T}_{\text {reg }}$ cells is presented.
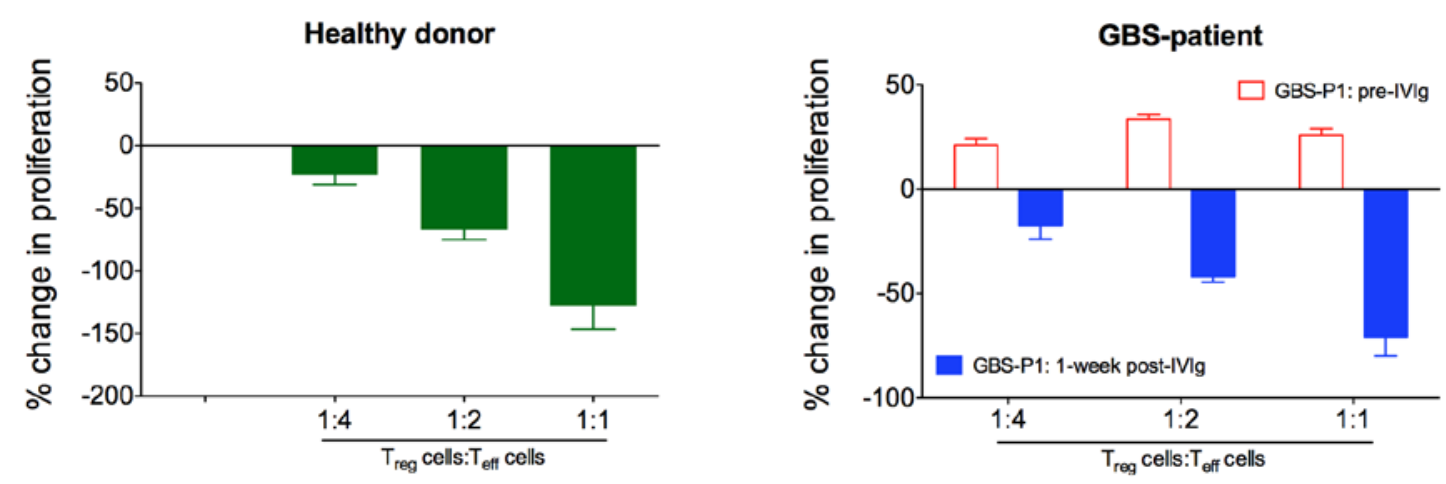
Fig. 5 The proposed mechanisms involved in the reciprocal regulation of Th1/Th17 cells and $\mathbf{T}_{\text {regs }}$ cells by IVIg. Exposure of effector $\mathrm{T}\left(\mathrm{T}_{\text {eff }}\right.$ ) cells to IVIg results in inhibition of activation, differentiation and cytokine secretion. Parallel, interaction of $\mathrm{T}_{\text {reg }}$ cells with IVIg or IVIg-modulated antigen presenting cells (APCs) leads to expansion and enhanced suppressive function of $\mathrm{T}_{\text {reg }}$ cells. These IVIg-modulated $\mathrm{T}_{\text {reg }}$ cells exhibit an increased expression of Foxp3 and Helios. IVIg-modulated $\mathrm{T}_{\text {reg }}$ cells are efficient inhibitors of effector $\mathrm{T}_{\text {eff }}$ cells. In addition to these direct effects, IVIg-mediated modulation of cytokine network as a result of altered cytokine production from APCs and neutralization of inflammatory cytokines can create a microenvironment favorable for $\mathrm{T}_{\text {reg }}$ cell expansion, while inhibiting $\mathrm{T}_{\text {eff }}$ cells.

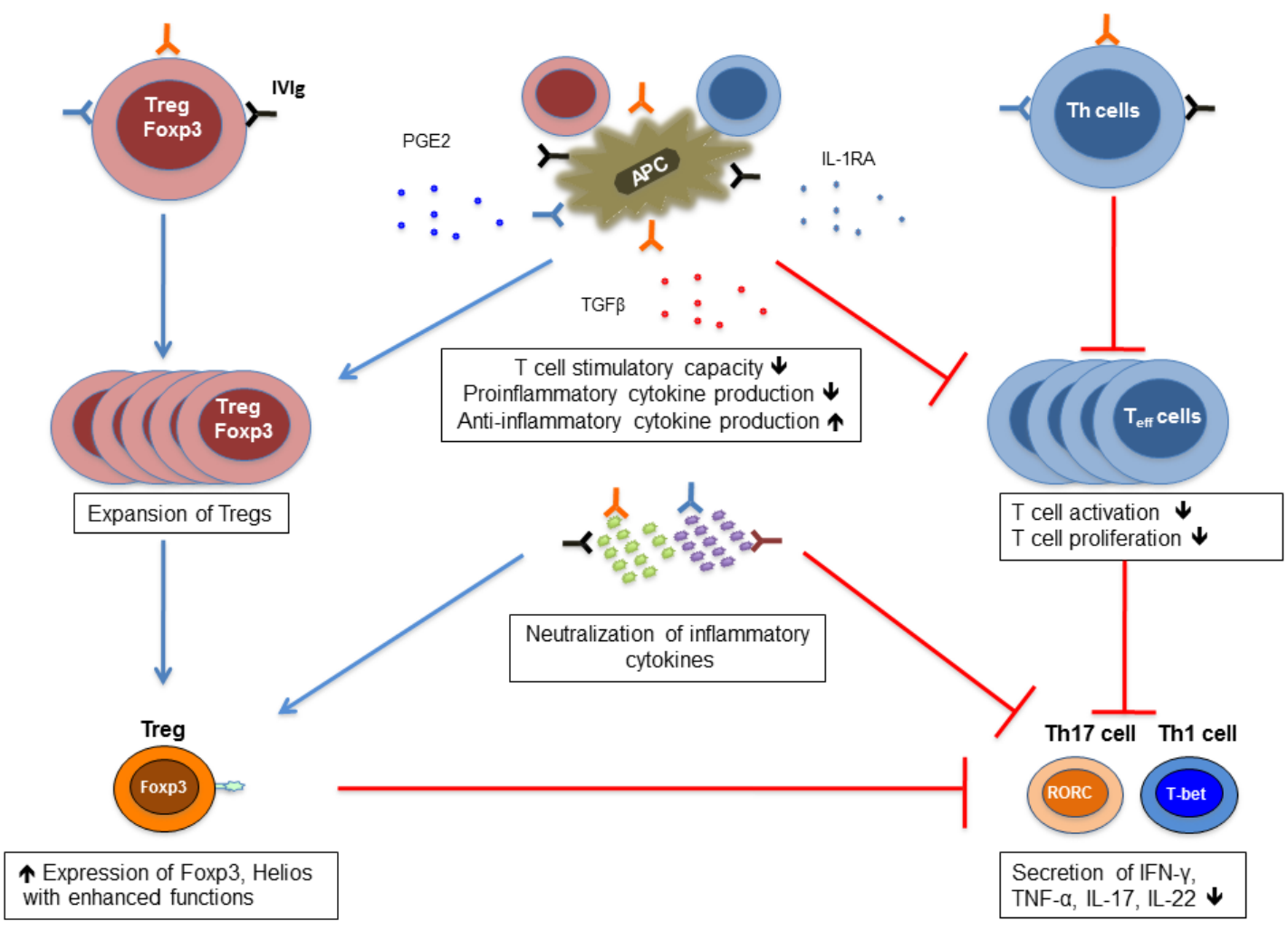

